\title{
Assessment of Undiscovered Conventional Oil and Gas Resources of Bonaparte Basin, Browse Basin, Northwest Shelf, and Gippsland Basin Provinces, Australia, 2011
}

Using a geology-based assessment methodology, the U.S. Geological Survey estimated means of 4.7 billion barrels of undiscovered oil and 227 trillion cubic feet of undiscovered natural gas in three major offshore petroleum basins of northwest Australia and in the Gippsland Basin of southeast Australia.

\section{Introduction}

The U.S. Geological Survey (USGS) assessed the potential for undiscovered conventional oil and gas fields within Australia's major offshore petroleum-bearing geologic provinces as part of the USGS World Petroleum Resources Project (fig. 1). Four geologic provinces as defined by the USGS were assessed in this study. Of these, three are mostly offshore of northwest Australia and include the Bonaparte Basin Province, Browse Basin Province, and the Northwest Shelf Province. The Northwest Shelf Province encompasses the northern offshore portions of the Carnarvon and Canning Basins. The fourth geologic province, the Gippsland Basin Province on the southeast coast of Australia, includes resources both onshore and offshore. Many of the basins and sub-basins within these provinces originated with basinal extension followed by a post-rift thermal subsidence phase that produced carbonate-platform deposits or prograding clastic wedges typical of passive margins. Additionally, single or multiple compressional events occurred during their complex tectonic histories, which resulted in constructive or destructive trap formation.
The methodology for the assessment included a detailed geologic framework description for each province based on published literature and the definition of total petroleum systems (TPSs) and assessment units (AUs). Exploration and discovery history was a critical part of the methodology used to estimate sizes and numbers of undiscovered accumulations. Each assessment unit was assessed for undiscovered oil and nonassociated gas accumulations. Coproduct ratios were used to calculate the volumes of associated gas (gas in oil fields) and natural gas liquids.

In the Bonaparte Basin Province, a Paleozoic-Mesozoic Composite TPS was defined on the basis of where petroleum source and reservoir rocks reflect the complex and progressive tectonic and depositional evolution of the region. Four AUs were defined within the various sub-basins or sub-basin complexes of the province on the basis of varying tectonic history, primary source rock, trap formation, and reservoirs. The four AUs are (1) the South Petrel Sub-Basin AU, (2) the Londonderry High-North Petrel AU, (3) the Vulcan Sub-Basin AU, and (4) the Malita Graben-Sahul Platform AU.

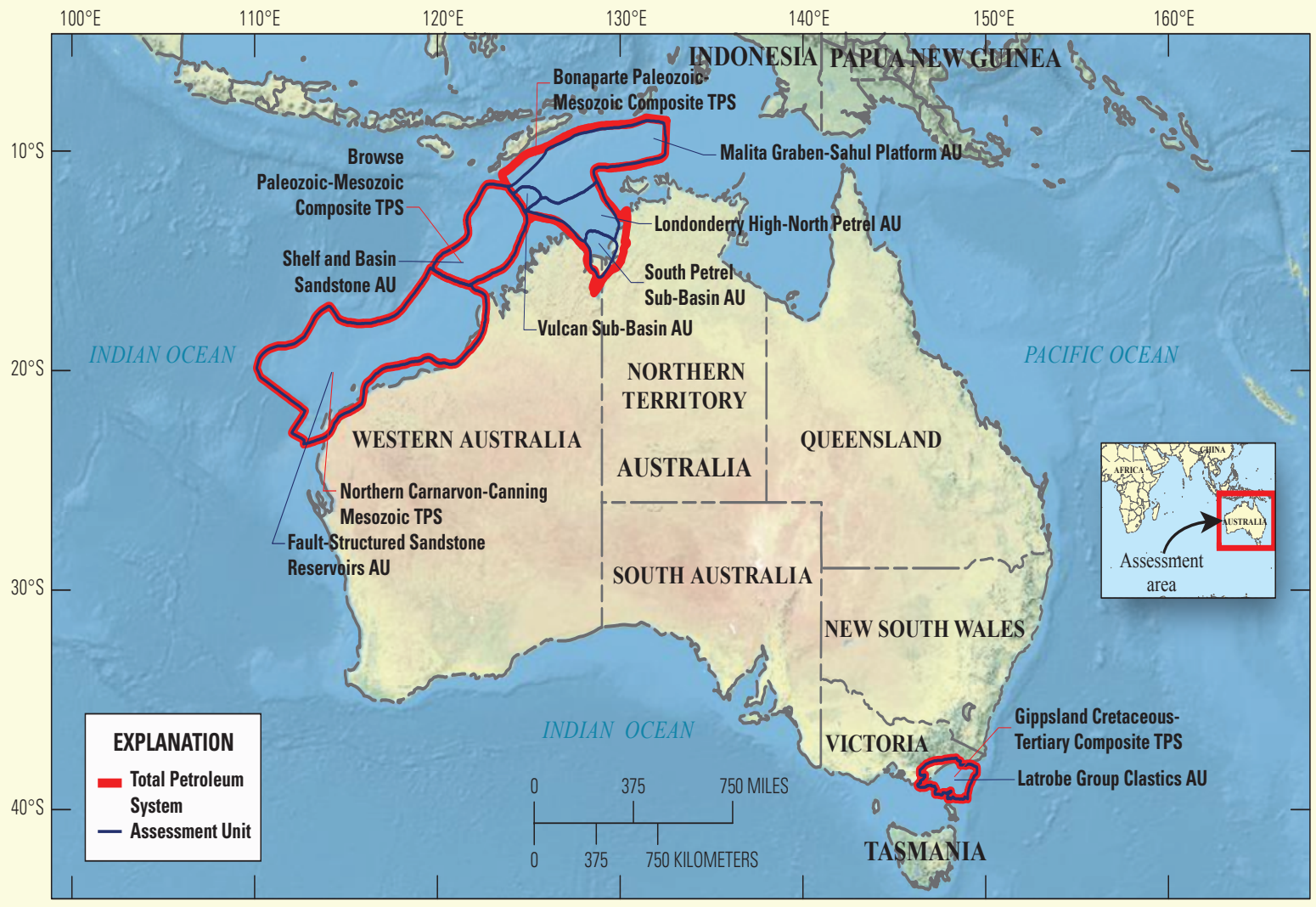

Figure 1. Locations of four geologic provinces of Australia assessed in this study. 
Table 1. Assessment results for Australia's four major offshore petroleum provinces.

[MMBO, million barrels of oil; BCFG, billion cubic feet of gas; MMBNGL, million barrels of natural gas liquids. Results shown are fully risked estimates. For gas fields, all liquids are included under the NGL (natural gas liquids) category. Undiscovered gas resources are the sum of nonassociated and associated gas. F95 represents a 95 -percent chance of at least the amount tabulated. Other fractiles are defined similarly. Fractiles are additive under the assumption of perfect positive correlation. Largest expected oil field size in MMBO; gas is in BCFG. Shading indicates not applicable]

\begin{tabular}{|c|c|c|c|c|c|c|c|c|c|c|c|c|c|c|}
\hline \multirow{3}{*}{$\begin{array}{l}\text { Total petroleum systems } \\
\text { (TPS) } \\
\text { and assessment units (AU) }\end{array}$} & \multirow{3}{*}{$\begin{array}{l}\text { Field } \\
\text { type }\end{array}$} & \multirow{3}{*}{\begin{tabular}{c|} 
Largest \\
expected \\
mean \\
field size
\end{tabular}} & \multicolumn{12}{|c|}{ Total undiscovered resources } \\
\hline & & & \multicolumn{4}{|c|}{ Oil (MMBO) } & \multicolumn{4}{|c|}{ Gas (BCFG) } & \multicolumn{4}{|c|}{ NGL (MMBNGL) } \\
\hline & & & F95 & F50 & F5 & Mean & F95 & F50 & F5 & Mean & F95 & $\mathrm{F} 50$ & F5 & Mean \\
\hline \multicolumn{15}{|c|}{ Bonaparte Basin Province, Paleozoic-Mesozoic Composite TPS } \\
\hline \multirow{2}{*}{ South Petrel Sub-Basin AU } & Oil & 18 & 43 & 77 & 138 & 82 & 42 & 112 & 268 & 128 & 1 & 3 & 7 & 3 \\
\hline & Gas & 1,197 & & & & & 1,882 & 4,365 & 9,193 & 4,804 & 57 & 133 & 283 & 147 \\
\hline \multirow{2}{*}{$\begin{array}{l}\text { Londonderry High-North Petrel } \\
\text { AU }\end{array}$} & Oil & 0 & 0 & 0 & 0 & 0 & 0 & 0 & 0 & 0 & 0 & 0 & 0 & 0 \\
\hline & Gas & 1,076 & & & & & 5,886 & 10,431 & 17,600 & 10,905 & 72 & 127 & 215 & 133 \\
\hline \multirow{2}{*}{ Vulcan Sub-Basin AU } & Oil & 26 & 55 & 121 & 257 & 134 & 160 & 389 & 870 & 435 & 5 & 12 & 26 & 13 \\
\hline & Gas & 222 & & & & & 127 & 350 & 1,091 & 447 & 5 & 14 & 45 & 18 \\
\hline \multirow{2}{*}{$\begin{array}{l}\text { Malita Graben-Sahul Platform } \\
\text { AU }\end{array}$} & Oil & 103 & 329 & 668 & 1,259 & 714 & 360 & 757 & 1,474 & 815 & 11 & 23 & 45 & 25 \\
\hline & Gas & 7,071 & & & & & 15,328 & 34,896 & 70,159 & 37,791 & 1,014 & 2,492 & 5,778 & 2,825 \\
\hline \multicolumn{15}{|c|}{ Browse Basin Province, Paleozoic-Mesozoic Composite TPS } \\
\hline \multirow{2}{*}{ Shelf and Basin Sandstone AU } & Oil & 49 & 325 & 594 & 1,077 & 633 & 1,072 & 2,033 & 3,730 & 2,166 & 32 & 62 & 113 & 66 \\
\hline & Gas & 6,979 & & & & & 14,384 & 33,366 & 67,854 & 36,324 & 438 & 1,018 & 2,091 & 1,110 \\
\hline \multicolumn{15}{|c|}{ Gippsland Basin Province, Cretaceous-Tertiary Composite TPS } \\
\hline \multirow{2}{*}{ Latrobe Group Clastics AU } & Oil & 24 & 87 & 133 & 200 & 137 & 133 & 253 & 451 & 267 & 5 & 14 & 37 & 16 \\
\hline & Gas & 439 & & & & & 1,128 & 2,152 & 3,879 & 2,282 & 52 & 99 & 181 & 105 \\
\hline \multicolumn{15}{|c|}{ Northwest Shelf Province, Northern Carnarvon-Canning Mesozoic TPS } \\
\hline \multirow{2}{*}{$\begin{array}{l}\text { Fault-Structured Sandstone } \\
\text { Reservoirs AU }\end{array}$} & Oil & 165 & 1,695 & 2,880 & 4,729 & 3,001 & 1,911 & 3,464 & 5,964 & 3,640 & 80 & 207 & 572 & 256 \\
\hline & Gas & 14,960 & & & & & 64,637 & 120,995 & 209,534 & 127,002 & 1,431 & 2,777 & 5,001 & 2,935 \\
\hline $\begin{array}{l}\text { Total conventional } \\
\text { resources }\end{array}$ & & & 2,534 & 4,473 & 7,660 & 4,701 & 107,050 & 213,563 & 392,067 & 227,006 & 3,203 & 6,981 & 14,394 & 7,652 \\
\hline
\end{tabular}

In the Browse Basin Province, the Paleozoic-Mesozoic Composite TPS was defined on the basis of oil and gas generated primarily from Upper Jurassic through Lower Cretaceous organic-rich shales that were deposited in restricted-marine environments. The Shelf and Basin Sandstone AU was defined within this TPS to encompass potential alluvial-deltaic, slope-channel, and basin-floor sandstone reservoirs.

In the Northwest Shelf Province, the Northern Carnarvon-Canning Mesozoic TPS includes oil and gas generated from Triassic and Jurassic organic-rich shales. The Fault-Structured Sandstone Reservoirs AU was defined within the TPS to include reservoirs ranging from alluvial-deltaic to deep marine sandstones and pinnacle and patch reefs.

In the Gippsland Basin Province, the Cretaceous-Tertiary Composite TPS includes oil and gas generated from mixed terrestrial and algal (lacustrine and marine) sources. The Latrobe Group Clastics AU was defined to include mainly Upper Cretaceous to Paleocene sandstone reservoirs.

\section{Resource Summary}

The USGS assessed undiscovered conventional oil and gas resources in seven assessment units within four major hydrocarbonproducing geologic provinces of Australia (table 1). The resulting mean totals for conventional resources are (1) 4,701 million barrels of oil (MMBO), ranging from 2,534 to 7,660 MMBO; (2) 227,006 billion cubic feet of gas (BCFG), ranging from 107,050 to 392,067 BCFG; and (3) 7,652 million barrels of natural gas liquids (MMBNGL), ranging from 3,203 to 14,394 MMBNGL.
Of the mean oil total of 4,701 MMBO, about 64 percent is estimated to be in the Fault-Structured Sandstone Reservoirs AU of the Northwest Shelf Province (mean of 3,001 MMBO). Two AUs in other provinces are estimated to have potential oil volumes greater than 500 MMBO: the Shelf and Basin Sandstone AU in the Browse Basin Province (mean of $633 \mathrm{MMBO}$ ) and the Malita Graben-Sahul Platform $\mathrm{AU}$ in the Bonaparte Basin Province (mean of $714 \mathrm{MMBO}$ ).

For the mean undiscovered gas total of 227,006 BCFG, about 58 percent is estimated to be in the Fault-Structured Sandstone Reservoirs AU of the Northwest Shelf Province (mean total of 130,642 $\mathrm{BCFG}$ ). The Bonaparte Basin Province is estimated to have potential gas volumes greater than 50,000 BCFG (mean of 55,325 BCFG), and the Browse Basin Province is estimated to have potential gas volumes greater than 35,000 BCFG (mean of 38,490 BCFG). Overall, the assessment indicates that more than 97 percent of the undiscovered oil and gas resources are offshore.

\section{For Further Information}

Supporting studies of the geologic models and the methodology used in the assessment of Australia basins are in progress. Assessment results are available at the USGS Energy Program Website: http:// energy.cr.usgs.gov/oilgas/.

\section{Australia Provinces Assessment Team:}

Richard M. Pollastro, Michael E. Brownfield, Ronald R. Charpentier, Troy A. Cook, Timothy R. Klett, Mark A. Kirschbaum, Janet K. Pitman, and Christopher J. Schenk. 